\title{
Lifelong Learning as a Response Toward Learning Society
}

\author{
W. Yulianingsih, I.K.A. Johnyartha, S. Mardliyah \\ Universitas Negeri Surabaya \\ Surabaya. Indonesia \\ wiwin.yulianingsih@yahoo.co.id
}

\begin{abstract}
The importance of lifelong learning is in accordance with human life in fulfilling the learning needs and the education needs. The existence of lifelong learning is caused by the appearance of learning needs that keeps growing along with human life. People get an education through several methods. Firstly, they get it from their families and neighbors where they live. Such process of education is known as an informal education. Secondly, people get an education through school and known as a formal education. Third, education is gotten through the social life and known as a nonformal education. There is a learning process within these three educational processes. Such processes are used to improve a quality within a person and the society because they provide knowledge, skill, moral values, attitude and functional understanding. Therefore, the spirit of learning needs to be enhanced by the people and society. A society that is open to the learning is a society that can grow to a betterment of life. Learning activity must be the life needs and social habit.
\end{abstract}

Keywords—lifelong learning; response; learning society;

\section{INTRODUCTION}

The concept of lifelong education gives a signal that education can be implemented for every human being in the space of his life. "To learn as long as to live" and learning has no boundaries (Burness \& Snider: 1997). First, education can be obtained through the family and the environment in which the individual lives, which later became known as an informal education. Second, education is obtained by the human being in the school environment which is then known as a formal education. Third, education can be followed by humans in the community or social life, which became known as a nonformal education. The three types of education are followed by humans throughout their lives and can reach a broad target and can progress in a large area also, at the same time and on an ongoing basis. In such conditions, everyone in his rightfulness as a person, a family member, and a citizen, in every time has a chance to attend education throughout his life. The three educational processes have also contained the process of learning so that the humans can learn in the scope of informal learning, formal learning, and non-formal learning. These three lessons are aimed at improving the personal quality and throughout their long life because in the learning process every human being can acquire a knowledge, skills, moral values, attitude and functional understanding (Rubenson \& Directorate: 2007).

Duke (2006: 15) stated that the term of education is often used in relation to statements about schools and teaching process at schools. In its broadest sense, an education can encompass all the educational experiences that experienced by most people in each part of their general life. Of course, the possibility of receiving education through life experiences or otherwise using a lot of time in school but minimal education in life is widely acknowledged in the expression of everyday life. Education and schooling are concerned with a general understanding of learning, but they are not same at all. Thus, it can be asserted that education is a more general process and not limited only to the result of contact with and or school.

Coombs and Ahmed, (2005: 9-10) argued that education is learning in a broad sense, regardless of where, when and how learning takes place. Thus, education encompasses broader issues, not only includes academic knowledge or skills and school lessons, but also the ability to work for the provision of life, the quality of life, the work that includes the needs of the household, the development of appreciation of aesthetics and ways of analytic thinking, the formation of attitudes and values, knowledge and information about new things (Mishra \& Koehler: 2006).

Historically, Pramudia (2013: 43-45) mentioned that lifelong learning concept cannot be separated from the process of building human civilization. The perspective of learning from the cradle to the grave (the cradle-to-grave) is widely known and promoted in many countries. As time goes by and the variation of the learning needs, the concepts and forms of learning and education are becoming more widespread, synergizing with passion and the need to learn continuously on various occasions. The development of human potential for lifelong learning recognizes that every individual has the potential to learn while accepting some of the limitations contained in the individual's potential. For that, we can make quantum leaps in reaching our potential skill and we can do it if we have a chance and a pleasant experience. Furthermore, humans must have the potential to support themselves or called supportive potentials, continuously, keep processes, stimulates, empowers, individuals, knowledge, values, and 
skills until they reach the level of understanding which is often obtained from the knowledge of applicative skills. Learning is no longer dichotomized into a place, building and time to gain knowledge (school), or to apply knowledge (at workplace, agency or office). Today people are flooded with more diverse information than they can handle. Lifelong learning is an important challenge to find the future of our society. Lifelong learning more than adult education, training, skill education, it is the mindset of a habit for people to gain meaning in learning. Life-long learning creates a challenge to understanding, exploring and supporting new important dimensions for education. Everybody experiences learning process in their life. According to Ahmadi, (2014: 129-130), the dimensions are 1). Self-directed learning (self-directing learning). 2). Learning on demand (learning on demand). 3). Collaborative learning (collaborative learning) 4).Learning organization (organization learning)

These approaches require new media and technology to be adequately supported. The lifelong learning theory should investigate the new frameworks for learning that are required by major and rapid changes in the world of education and employment or work. These changes: 1). Prevalence of high technology that increases the work needs to be supportive to learn on the basis of demands because it covers all the impossible concepts. 2). Unusual changes which cannot be avoided in the age of the profession that requires lifelong learning and, 3). The depth of the difference in opportunities offered to an educated people and uneducated people (Merriam et. al.: 2012).

\section{RESUlt AND DISCUSSIONS}

The core of lifelong learning is all individuals must develop according to their potential optimally. Therefore lifelong education should be viewed holistically from the cradle to the end of life (Finger \& Asún, 2001). Within this framework, education is seen as a service to assist lifelong personal development in broader terms: development. Lifelong learning has the goal of creating learning to live (learning to be) and forming a learning society. Affirmed by Trisnamangsah (Pramudia, 2013), the goal of long-life education is not just for the change but also for the achievement of self-satisfaction from those who do the learning itself. Someone, group(s), community absolutely feel more confident with the results of their learning ability. In another perspective mentioned that there are at least two goals of long-life learning including self-directed goals or selflearning that purposed to (1) to adjust the constantly changing and evolving positive changes throughout human life (2) to prepare for a better life in the future. The background of the community of learning society are as expressed by Longworth $\mathrm{N}$ and Davies R (2010: 227) as follows: a). The learning society which provides the means of doing this is imminent. It provides a structural framework for action at the local level. b).One of the most effective ways to create a learning society is first to create a learning community in the cities, town, villages or regions which integrate their economic, political, educational, and environmental structures toward developing the talents and human potential of all their citizens. c). True learning communities are outward looking. People moving from one community to another should be able to recognize in each the ambience of learning and use it as a means of integration. d). Learning community would also be a caring community. It would have to make special provision for the allow learner and the late developer, the eccentric and the deranged, the damaged and the desperate.

According to Ivan Illich (1976), learning should not be insulated or isolated by space and time, because learning can be done in anywhere and anytime. At a time when information technology is not as advanced as it is today, Ivan Illich is already thinking about Learning Webs (network learning). In this case, Ivan Illich argues that knowledge should be used to solve problems and add the value to life. Whatever one's work and business, will always need to learn at every time, throughout his life. While the idea is poured by Paulo Freire, a Brazilian educator, Freire who was born and raised in the middle of this country that most of the poor and uneducated, even illiterate. Gramsci, emphasizes critical awareness, the importance of intellectuals that are part of everyday life and to the part played by so-called "common sense". Sudjana (2001: 224). People who love to study will also be a prerequisite for the growth of educated society.

Long life learning theory is stimulated by the thoughts of human learning theory, which recognizes the existence of the lifelong nature of one's learning activities (Kolb: 2014). Learning does not stop when one completes a formal or nonformal education but learning is a process of interaction and relationships that last throughout one's life in a particular social context until the end of death. That is, learning is a process of transforming one's own experience and will always occur when the individual interacts with the wider social environment. Start from the family environment, community, and school. Amplified by Jean Jacques Rousseau's opinion that "human beings must learn to live more adequately, as when we are born taking part of our citizenship rights, it should be the starting point of our work, as pedagogics whose have the freedom to learn. Nature will teach how we should learn and behave as living beings that have many advantages even almost perfect. Nature is a good teacher as well as a friend to mankind"

Taken from the side of a college student, states that learning the field of expertise is important but not enough. If the learner in the campus is only deep in his field of expertise (according to the department) of course he did not get much other learning experiences. Kai Mien Cheng's opinion (Samani, 2014: 182-183) is in line with Tony Wagner's research and Berny Trilling research with Thomas Fadel. Through a series of studies, Wagner (2008) finds what he calls the survival skills, including critical thinking skills and problem-solving, cross-cultural collaboration skills, and both verbal and written communication skills, an ability to search and analyze the information, curiosity, and imagination. Meanwhile, Trilling and Fadel (2009) proposed the so-called 21 st century skills that are critical thinking ability and problem 
solving, communication ability to innovate media and technology skills that includes information literacy, media literacy and ICT, also life and career skills that include adaptive flexibility and ability, initiative and self-directed capabilities, social skills and cross-cultural interaction, responsible productivity and leadership.

William Lovett (Sudiapermana, 2013: 135), urged to build public spaces and schools for the people who are representative and can be utilized optimally by the community. During the day the room is used by the children for primary and secondary education and at night used by the adults, for public lectures, morals, politics, reading rooms, discussions, musical entertainment, dancing and other forms of creation. The public space building includes a bathroom, small museum, or workshop room and science center. In line with what Josephine Macalister Brew says, education should be brought to places where people gather, such as public houses, licensed clubs, libraries and places where people feel at home. Educational attention should be on empowering the 'learned' (those who are able to entertain themselves, able to entertain strangers and be able to come up with new ideas). Furthermore, Brew adds that every human activity essentially has educational value in his work. In the informal education, learners need to have various cultural backgrounds and think about the meaning of life, positive thinking and ability to connect with others and flexible (Jenkins et Al.: 2009).

Bell Hooks (Sudiapermana, 2013: 209-210), an academic professor of English at City College of New York. A feminist and for her literacy is crucial to the future of the feminist movement, writing and skill awareness works well to eliminate the male dominance including the political awareness and labor market. She sees that literacy is more than just reading and writing literally, but it allows people, especially those who are still marginalized and disseminated in society to gain their critical awareness. It also added that education can not only be obtained in the classroom but can be obtained anywhere and from anyone. She referred to his book 'Communities of Resistance'. Bell Hooks says education as a practice of liberation, which everyone can learn. Teaching is not just a variety of information or transfer of knowledge but for various in the spiritual and intellectual growth of students. Teaching by respecting and nurturing the souls of students is very important to foster self-confidence and intellect. When we teach, we must provide a conducive atmosphere and full of intimacy.

The concept of a society fond of learning put forward Debtors (Santoso, 2010: 230), states that: Education the necessary utopia, the focus of this is on personal and social development, the enriching of people through the learning process and recognition. Ranson states, "tried to describe for democracy in which there would be many achieved citizens because the educated people would join the achieved. That education requires the euphoria focus of this on personal and community development. Enrichment of people through learning processes and discoveries. Ranson tries to describe what society's learning is and includes education for democracy where there will make citizens active because educated people will be active together.

While needs and requirement in Romania adult education and training system using modern methods. A modern and efficient adult training system bring undoubtedly an added value to a human resource quality a professional. A staff body in institutions and companies, able to raise the performance level and needs another team building, benchmarking coaching, and brainstorming.

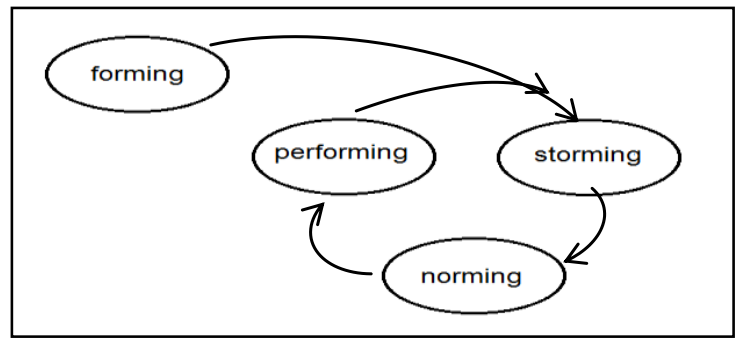

Fig1. Model theory of group formation

1) Forming

At the forming stage, new groups are formed and tasked. Where members tend to be individualistic, selfish and tend to pay attention to individual skills, even though they have good intentions only have not known each other and trust each other. More time is spent in adapting, planning and gathering information.

2) Storming

Once a group is formed and adapt, it progresses to the second stage, storming. Where this stage of the group begins to develop ideas related to their respective tasks. Discuss the issues and problems they need to resolve, which of their functions and which leadership modes they will receive. Members of his group began to open up and began to put forward their own ideas and perspectives. Discusses the issues and problems they have to resolve, their functions and which leadership model will be accepted Members of the group begin to open up and begin to put forward their ideas and perspectives. This stage is very important for the development of the group itself. Group members are wise, wise and open to different opinions because at this stage there is often a conflict of disagreement.

3) Norming

At this stage, the members of the group begin to trust each other. They begin to find roles and responsibilities clearly, and the group begins to find the rhythm as the rules deal, the value they use. This stage also makes the members comfortable and continues to contribute to the progress of the group.

4) Performing

Furthermore, at this stage, the group begins to function in accordance with the roles and functions of 
each. They finish the job smoothly without any unnecessary conflict. The group members are interdependent and complement each other, they are sensitive to the circumstances and situations, communicate effectively and run smoothly.

5) Adjusting and Transforming

This is the last stage, there is a process that runs while carrying out the group's activities and the whole process perception, motivation, purpose, or organizations, independence interact.

\section{CONCLUSION}

Humans need education in order to adapt and control changes that occur. Thus, following the principle of long life education, education is not only done at school but also at a non-formal situation, at a community. Someone in the world of work requires new knowledge and new skills to be more successful in the world of work. Society needs continuous education in tune with new demands in the world of work or other necessities of life. People fond of learning will be formed if every citizen is always looking for and find something new and meaningful. Improve their ability and develop themselves through learning activities. Learning activities have become the necessities of life and community habits. Learning activities undertaken by every society are not limited only to know (learning how to learn), nor learn only to solve problems (learning how to solve problems). The learning activities they do are focused on the importance and progress of life (Learning how to be or learning how to live). People love learning as well as a prerequisite for the growth of educated society.

\section{REFERENCES}

[1] Ahmadi, Rulam. Pengantar Pendidikan: Asas dan Filsafat Pendidikan. Ar-Ruzz Media. Jogjakarta.2014.

[2] Duke, C. Australian Perspectives in Lifelong Education. Mel-bourne: Australia Council for Education Research. 2006

[3] Longworth, Norman, and Davies, W.Keith. Lifelong learning: Learning.London: Kogan Page 2006.

[4] Pramudia, Rahmat Joni. Belajar Sepanjang Hayat: Konsep, Kebijakan dan Aplikasi dalam Pendidikan Nonformal menuju Masyarakat Berpengetahuan. Bandung. EDUKASIA Press. 2013

[5] Samani, Muchlas. Mohon Maaf...Masih Compang-camping: Kumpulan Catatan Sebagai Rektor Universitas Negeri Surabaya, Jabatan 20102014. Surabaya. Unesa Inuversity Press. 2014.

[6] Santoso, Slamet. Teori Konsep Dasar PLS. Bahan Kuliah Konsep Dasar PLS di Jurusan PLS FIP Unesa. Untuk Kalangan Sendiri. 2010

[7] Sudiapermana, Elih. Pendidikan Nonformal danInformal : Tokoh dan Pemikiran. Bandung. Edukasia Press. 2013.

[8] Sudjana,H. Djuju. Pendidikan Luar Sekolah: Wawasan, Se-jarah perkembangan, Filsafat, Teori Pendukung, Asas. (Bandung: Falah Production), 2001

[9] ------------ Pendidikan Non Formal: Wawasan, Sejarah perkembangan, Filsafat, Teori Pendukung, Asas. (Ban-dung: Falah Production), 2004).

[10] Finger, M., \& Asún, J. M. (2001). Adult education at the crossroads: Learning our way out. Zed Books.

[11] Kolb, D. A. (2014). Experiential learning: Experience as the source of learning and development. FT press.

[12] Merriam, S. B., Caffarella, R. S., \& Baumgartner, L. M. (2012). Learning in adulthood: A comprehensive guide. John Wiley \& Sons.

[13] Jenkins, H., Purushotma, R., Weigel, M., Clinton, K., \& Robison, A. J. (2009). Confronting the challenges of participatory culture: Media education for the 21 st century. Mit Press.

[14] Rubenson, K., \& Directorate, L. P. (2007). Determinants of formal and informal Canadian adult learning insights from the adult education and training surveys. Toronto: Human Resources and Social Development Canada.

[15] Burness, P., \& Snider, W. (1997). Learn \& Live. The George Lucas Foundation, PO Box 3494, San Rafael, CA 94912.

[16] Mishra, P., \& Koehler, M. J. (2006). Technological pedagogical content knowledge: A framework for teacher knowledge. Teachers college record, 108(6), 1017. 